\title{
Taxonomic value of the leaf micro-morphology and quantitative phytochemistry of Jatropha integerrima Jacq. and Jatropha podagrica Hook. (Euphorbiaceae)-known horticultural plants in Nigeria
}

Opeyemi Saheed Kolawole1, Mahboob Adekilekun Jimoh², Fred Yakubu \& Emmanuel Chukwudi Chukwuma ${ }^{3}$

1 Department of Biological Sciences, Faculty of Science, Federal University, Kashere, Gombe State.

2 Department of Biological Sciences, Osun State University, Osogbo, Osun State, Nigeria

3 Forestry Research Institute of Nigeria, Jericho Hills, Ibadan, Oyo State, Nigeria

\section{Correspondence}

OS. Kolawole

E-mail:

kolawoleopeyemisaheed@gmail.com +2348060909011

Received: 14 August 2016

Accepted: 28 February 2017

Published on-line: 14 March 2017

\section{Resumen}

Valor taxonómico de la micromorfología de la hoja y la fitoquímica cuantitativa de Jatropha integerrima Jacq. y Jatropha podagrica Hook. (Euphorbiaceae)-conocidas plantas hortícolas en Nigeria

Se examinó la micromorfología y la fitoquímica cuantitativa de $\mathrm{J}$. integerrima y J. podagrica para para identificar caracteres útiles para la delimitación taxonómica, siguiendo protocolos estandarizados, descritos por autores anteriores. Ambas especies son hipostómicas (paracíticas). Los tricomas (multicelulares, no glandulares) estaban presentes sólo en la superficie adaxial de J. integerrrima y ausentes en otras superficies epidérmicas. Los análisis fitoquímos también señalaron pequeñas diferencias en la cantidad de compuestos bioactivos presentes en ambas especies. El contenido de fenol es el mayoritario en ambas especies: $37.65 \%$ en J. integerrima y $36.13 \%$ en J. podagrica. Las semejanzas y diferencias de los caracteres epidérmico-foliares y contenidos fitoquímicos pueden ser empleadas para delimitar taxonomicamente ambas especies.

Palabras clave: Jatropha, Microcaracteres, Fitoquímica, Taxonomía.

\begin{abstract}
The leaf micro-morphology and quantitative phytochemistry of $\mathrm{J}$. integerrima and J. podagrica were examined to find useful characters for the delimitation of taxa, following standard protocols as described by previous authors. Both species are hypostomatic (paracytic). Trichome (multicellular, non-glandular) are only present on the adaxial surface of $J$. integerrima and absent in other epidermal surfaces. Phytochemical analysis also showed little differences in the amount of bioactive compounds present in both species. Phenol contents are the highest in the two species: $37.65 \%$ in $\mathrm{J}$. integerrima and $36.13 \%$ in J. podagrica. The similarities and differences in the foliar epidermal characters and phytochemical content can be used to delimit the two studies species, as taxonomic characters.
\end{abstract}

Key words: Jatropha, Micro-characters, Phytochemistry, Taxonomy. 


\section{Introduction}

The genus Jatropha is a member of the Euphorbiaceae, and comprises of approximately 175 species of succulent, caudiciform, herbaceous perennials and woody plants. It is characterized by simple to palmately arranged leaves; 3,5 or 7 lobed or divided into a maximum of 11 segments (Abdulrahaman et al., 2014). The genus is diverse, occurring in tropical and sub-tropical areas of the world. Extracts from different parts such as leaves, stem, bark and roots of Jatropha species have been used in ethno-medicines for a long time (Duke, 1985).

Jatropha integerrima Jacq.is an erect ornamental evergreen shrub, native to West Indies and grows commonly in Southern parts of India (Krishan \& Paramathma 2009). It grows from 3 to 10 feet tall and to almost tree-like proportions with age in frost free climates. The leaves are 3 to 6 inch long by 2 inch wide, green and velvetly on upper surface and flecked with purple below, have sharp points on the lobes and are held on long leaf stems. J. integerrima flowers are $1 \mathrm{inch}$ wide fivepetaled deep red with yellow stamens are held in branched clusters on 4 inch long stalks at the branch tips. Various parts of J. integerrima are traditionally used as purgative, styptic, emetic, in treatment of warts, tumours, rheumatism, herpes, pruritis, toothaches, scabies, eczema and ringworm (Kirtikar et al. 2002). The leaves and branches of the plant have been shown to hold cholinesterase activity while latex of the plant has demonstrated anti-cancer activity (Gupta and Gupta 1997, Wele et al. 2007, Sharma and Singh 2010).

Jatropha podagrica Hook is a shrub native to tropical America. J. podagrica is an ornamental plant which is also employed to cure various infections in traditional medicine. J. podagrica is known for many biological activities such as antitumour, antimicrobial, molluscicidal and antiinsect (Kupchan et al. 1970, Bhushan et al. 2008). Different parts of $J$. podagrica are also used for antipyretic, diuretic, choleretic and purgative effects (Irvine 1961). Various medicinal and pesticidal properties, including antimicrobial, antitumour and insect antifeedant activities, have also been attributed to this plant (Aiyelaagbe et al. 1998, Aiyelaagbe et al. 2000, Bhaskarwar et al. 2008, Sanni 1988).

Previous phytochemical investigations of $J$. podagrica led to the isolation of japodic acid, erytrinasinate (Aiyelaagbe \& Gloer 2008), nhexacosane, $\beta$-amyrin, lupeolpalmitate, quercetin, apigenin, vitexin, isovitexin, rutin (Odebiyi 1985), podacycline A, podacycline B and 3-acetylaleuritolic acid (Ee et al. 2005).

Earlier studies on the genus were examined on the basis of morphological (Dehgan and Webster 1979, Dehgan 1980), wood anatomy (Oladipo \& Illoh 2012a), numerical approach to the taxonomy using quantitative phytochemical parameters (Kolawole et al. 2014), leaf and seed electrophorensis (Oladipo \& Illoh 2012b, Oladipo et al. 2008), leaf epidermal features (AbdulRahaman \& Oladele 2010), quantitative phytochemical constituents (Kolawole et al. 2014), palynological and carpological studies (AbdulRahamnan et al. 2014) and recently morphometric study (Kolawole et al. 2016). Metcalfe \& Chalk (1972) had pointed out that the historical development of botany has been such that physiological and anatomical investigations of plants have been unnecessarily separated from the studies of their systematic arrangement.

This paper aims to provide a comprehensive description and add to scanty information that is available in literatures on the foliar epidermal and phytochemical properties, with a view of finding additional diagnostic characters that may be used to distinguish the species.

\section{Material and methods}

\section{Sample collection and identification}

Fresh specimens of $J$. intergerrima and $J$. podagrica (Fig. 1) were collected from different locations in Nigeria and were identified at the Forest Herbarium, Ibadan (FHI). Voucher specimens were prepared according to the established protocol of Soladoye et al. (2011). Each specimen was assigned with a specific voucher number: Jatropha intergerrima Jacq. FHI109864 and Jatropha podagrica Hook. FHI109871. Voucher specimens were deposited at the Forest Herbarium, Ibadan (FHI) (Holmgren et al., 1990).

\section{Sample preparation}

The dried leaves were ground into fine powder and transferred into airtight containers with proper labelling. They were then subjected to phytochemical screening which was carried out at the 

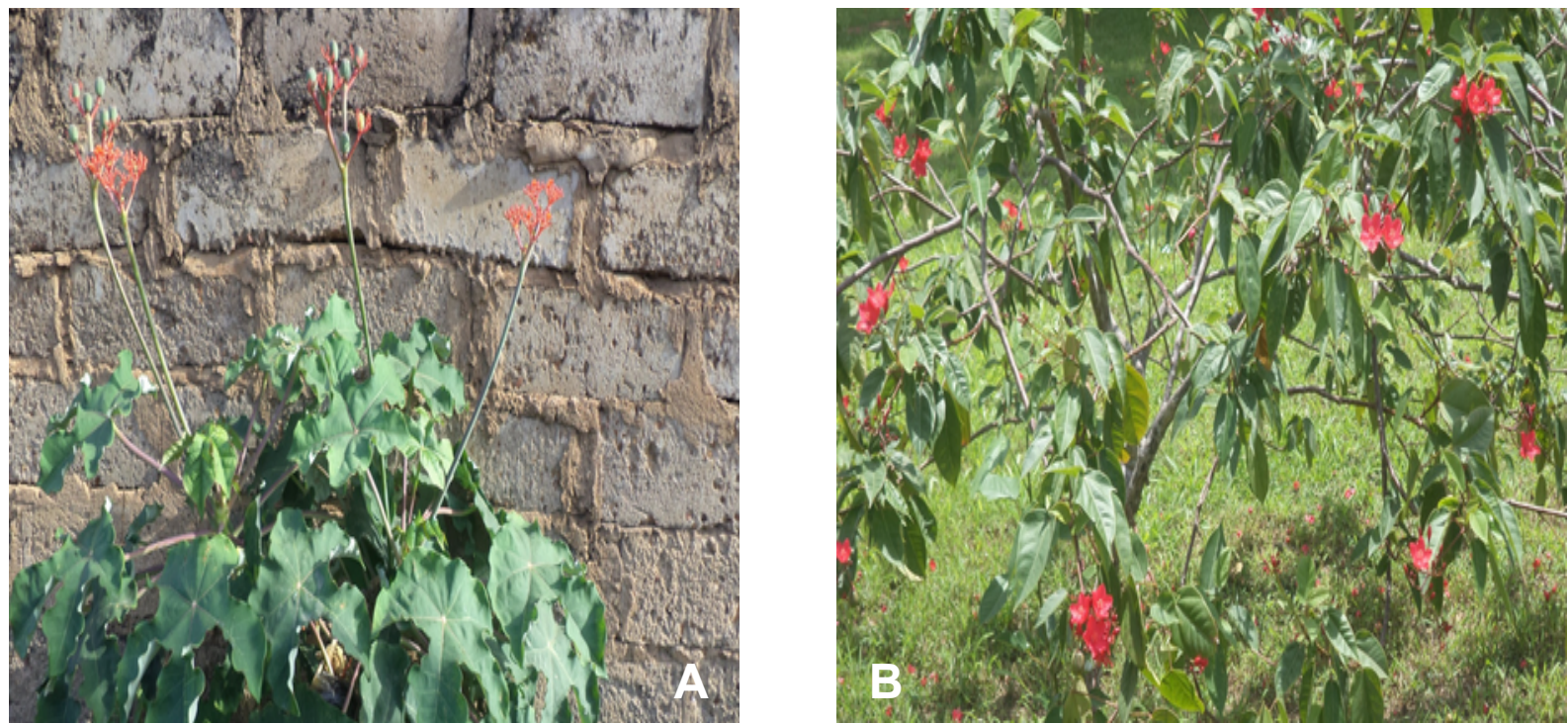

Figura 1. Especímenes vivos. A: Jatropha podagrica B: Jatropha integerrima.

Figure 1. Live specimens of the species studied. A: Jatropha podagrica B: Jatropha integerrima.

National Horticultural Research Institute (NIHORT), Ibadan, Nigeria. This screening was done to determine the biologically active compounds present in the plant parts. Procedures were adapted from earlier works for plant analysis as described below and reported by Sofowora (1993) and Trease \& Evans (2005). A detailed method of extraction, as well as purification techniques for active plant constituents described by Harborne (1998) and adopted by Soladoye \& Chukwuma (2012) were also employed for the phytochemical extraction of the plant materials.

\section{Foliar epidermal preparation}

About $2-5 \mathrm{~cm}^{2}$ of the leaves was obtained from fresh specimens of $J$. integerrima and $J$. podagrica were and soaked in well covered glass petridishes containing concentrated trioxonitrate (v) acid for 2-3hr. Upon the disintegration of tissues and indication of bubbles, the specimens were carefully transferred unto clean petri-dish and rinsed with distilled water before the epidermises were separated using forceps. The mesophyll tissues of the leaves were also cleared with camel brush. They epidermises were thereafter stained with Safranin 0 for 5 minutes and again rinsed and continuous changes of distilled water until excess stain is washed off. The stained tissues were carefully mounted in $25 \%$ glycerol, unto clear microscopic glass slides and ringed with nail vanish. They were then studied under an Olympus light microscope at different magnifications. Observations were taken from 20 fields of view for each epidermal surface (abaxial and adaxial), of the Jatropha species studied (Khatijah \& Zaharina 1998, Adedeji 2004, Chukwuma et al. 2014).

\section{Phytochemical analysis}

\section{Determination of tannins}

Tannin content was determined using the method outlined by Van-Burden \& Robinson (1981). $0.5 \mathrm{~g}$ of the dried powdered leave sample was weighed into a $50 \mathrm{ml}$ plastic bottle and $50 \mathrm{ml}$ of distilled water was added and then shaken thoroughly for about 1 hour. The solution was filtered into a 50 $\mathrm{ml}$ volumetric flask and made up to the mark. 5 $\mathrm{ml}$ of the filtrate was pipetted out into a test tube and mixed with $2 \mathrm{ml}$ of $0.1 \mathrm{M} \mathrm{FeCl}_{3}$ in $0.1 \mathrm{~N} \mathrm{HCl}$ and $0.008 \mathrm{M}$ potassium ferrocyanide. The absorbance was measured at $120 \mathrm{~nm}$ within $10 \mathrm{~min}$ (Edeoga et. al., 2005).

\section{Determination of flavonoids}

To determine the flavonoid content in the leaves of the Jatropha species studied, the aluminium chloride colorimetric method was employed. $1 \mathrm{ml}$ of each plant extract was mixed with $2 \mathrm{ml}$ of methanol, $0.2 \mathrm{ml}$ of $10 \%$ aluminium trichloride $\left(\mathrm{AlCl}_{3}\right), 0.2 \mathrm{ml}$ of $1 \mathrm{M}$ potassium acetate, and 5.6 $\mathrm{ml}$ of distilled water. The entire mixture was allowed to stand at room temperature for $30 \mathrm{~min}$ after which the absorbance was measured at 420 $\mathrm{nm}$. The total flavonoid content in each plant part 
was expressed in terms of standardized quercetin equivalent (QE) per $100 \mathrm{mg}$ of each extracted compound (Aiyegoro \& Okoh 2010).

\section{Determination of phytosteroids}

For this purpose, the crude extract of each leaf was mixed with $2 \mathrm{ml}$ of chloroform and concentrated sulphuric acid $\left(\mathrm{H}_{2} \mathrm{SO}_{4}\right)$ was added sidewise. The presence of steroids was noticed from the red colour produced in the lower layer of chloroform. To confirm further the presence of this phytochemical, another test was performed by mixing each crude extract of the plant materials with $2 \mathrm{ml}$ of chloroform. Two $\mathrm{ml}$ of concentrated $\mathrm{H}_{2} \mathrm{SO}_{4}$ and of acetic acid were then poured into the mixture and the development of greenish coloration indicated the presence of steroids (Soladoye \& Chukwuma 2012).

\section{Determination of cardiac glycosides}

Buljet's reagent (El-Olemy et al. 1994) was used to evaluate the cardiac glycoside content in the examined Jatropha species. For this purpose, $1 \mathrm{~g}$ of each powdered sample was soaked in $100 \mathrm{ml}$ of $70 \%$ ethanol for $2 \mathrm{hrs}$ before filtration. Using lead acetate and $\mathrm{Na}_{2} \mathrm{HPO}_{4}$ solution, the obtained extracts were purified before the addition of freshly prepared Buljet's reagent. The difference between the intensity of colours of the experimental and blank samples (distilled water and Buljet's reagent) gave the absorbance, which is proportional to the concentration of glycosides.

\section{Determination of alkaloids}

A weighed amount (5 g) of each powdered sample of the Jatropha leaves was transferred into a 250 $\mathrm{ml}$ beaker. $200 \mathrm{ml}$ of $10 \%$ acetic acid was added and then covered to stand for 4 hrs. Filtration was done, and concentration of the extracted content to one quarter of original volume was applied using a water bath. Drop-wise addition of concentrated ammonium hydroxide to the extract followed until the precipitate was complete. The entire solution was allowed to settle and collection of the precipitate was done by filtration (Harborne 1997, Obadoni \& Ochuko 2001) and then weighed.

\section{Determination of saponins}

The method described by Obadoni \& Ochuko (2001) was used for the determination of saponin. $100 \mathrm{~cm}^{3}$ of $20 \%$ aqueous ethanol was added into a conical flask containing $20 \mathrm{~g}$ of the powdered samples. The mixture was properly shaken together, and then heated over a hot water bath for 4 hours with continuous stirring at $55{ }^{\circ} \mathrm{C}$. It was filtered and re-extraction of residue was performed with $200 \mathrm{ml}$ of $20 \%$ aqueous ethanol. The combined extracts were then reduced to $40 \mathrm{ml}$ over water bath at $90{ }^{\circ} \mathrm{C}$ after which the concentrate was transferred into a $250 \mathrm{ml}$ separating funnel with the addition of $20 \mathrm{ml}$ diethyl ether, and shaken vigorously. The aqueous layer of the solution was recovered while the ether layer was discarded. The purification process was then repeated and thereafter, $60 \mathrm{ml}$ of n-butanol was added. The combined n-butanol extracts were washed twice with $10 \mathrm{ml}$ of $5 \%$ aqueous sodium chloride and the remaining solution was heated in a water bath. After evaporation the samples were dried in the oven to a constant weight, the saponin content was calculated as percentage at a wavelength of $380 \mathrm{~nm}$.

\section{Determination of phenol}

Total phenol content in each plant sample was determined using Folin-Ciocalteu's method as modified by Olajire \& Azeez (2011). $0.5 \mathrm{~mL}$ of the extract was added to $10 \mathrm{~mL}$ of deionized distilled water and $2.5 \mathrm{~mL}$ of $0.2 \mathrm{~N}$ Folin-Ciocalteu's phenol reagent. The mixture was allowed to stand at room temperature for $5 \mathrm{~min}$ and then $2 \mathrm{~mL}$ of sodium carbonate solution was added. The absorbance of the solution was measured at $760 \mathrm{~nm}$ after 2 hours of incubation using a spectrophotometer. Quercetin was used as standard for calibration curve.

All tests were carried out in triplicate and mean values were recorded appropriately.

\section{Results and discussion}

Results from this work showed that the leaves of $J$. integerrima and $J$. podagrica have important diagnostic features that can be useful in taxonomic studies. The leaves of the examined species are also rich in plant compounds. These characteristics exhibited by these important angiosperms are summarised in tables 1 and 2 respectively.

Epidermal cells were generally polygonal and numerous on the surfaces, while stomata paracytic in both species. Trichome is simple, long, multicellular and non-glandular on the adaxial surface of $J$. integerrima, and completely absent on abaxial surface and both surfaces of $J$. podagrica (Fig. 2). Similarity of the stomata complex in the two species is noteworthy, although stomata are larger in the former than in the latter. Salisbury 


\begin{tabular}{|c|c|c|c|c|c|c|c|}
\hline Species & $\begin{array}{c}\text { Leaf } \\
\text { surface }\end{array}$ & $\begin{array}{c}\text { Stomatal } \\
\text { type (s) }\end{array}$ & $\begin{array}{c}\text { Stomatal } \\
\text { frequency }(\%)\end{array}$ & $\begin{array}{l}\text { Stomatal } \\
\text { index }(\%)\end{array}$ & $\begin{array}{l}\text { Stomatal } \\
\text { size }(\mu \mathrm{m})\end{array}$ & $\begin{array}{c}\text { Anticlinal cell } \\
\text { wall pattern }\end{array}$ & Trichome \\
\hline \multirow{2}{*}{$\begin{array}{l}\text { Jatropha } \\
\text { integerrima }\end{array}$} & Adaxial & - & - & - & - & Straight, polygonal & Present \\
\hline & Abaxial & Paracytic & 100 & $14.50^{\mathrm{b}}$ & $47.69^{b}$ & Straight, polygonal & Absent \\
\hline \multirow{2}{*}{$\begin{array}{l}\text { Jatropha } \\
\text { podagrica }\end{array}$} & Adaxial & - & - & - & - & Straight, polygonal & Absent \\
\hline & Abaxial & Paracytic & 100 & $8.06^{\mathrm{a}}$ & $30.56^{a}$ & Straight, polygonal & Absent \\
\hline
\end{tabular}

Tabla 1. Características epidérmicas foliares de las especies estudiadas de Jatropha.

Table 1. Foliar epidermal characteristics of Jatropha species studied.
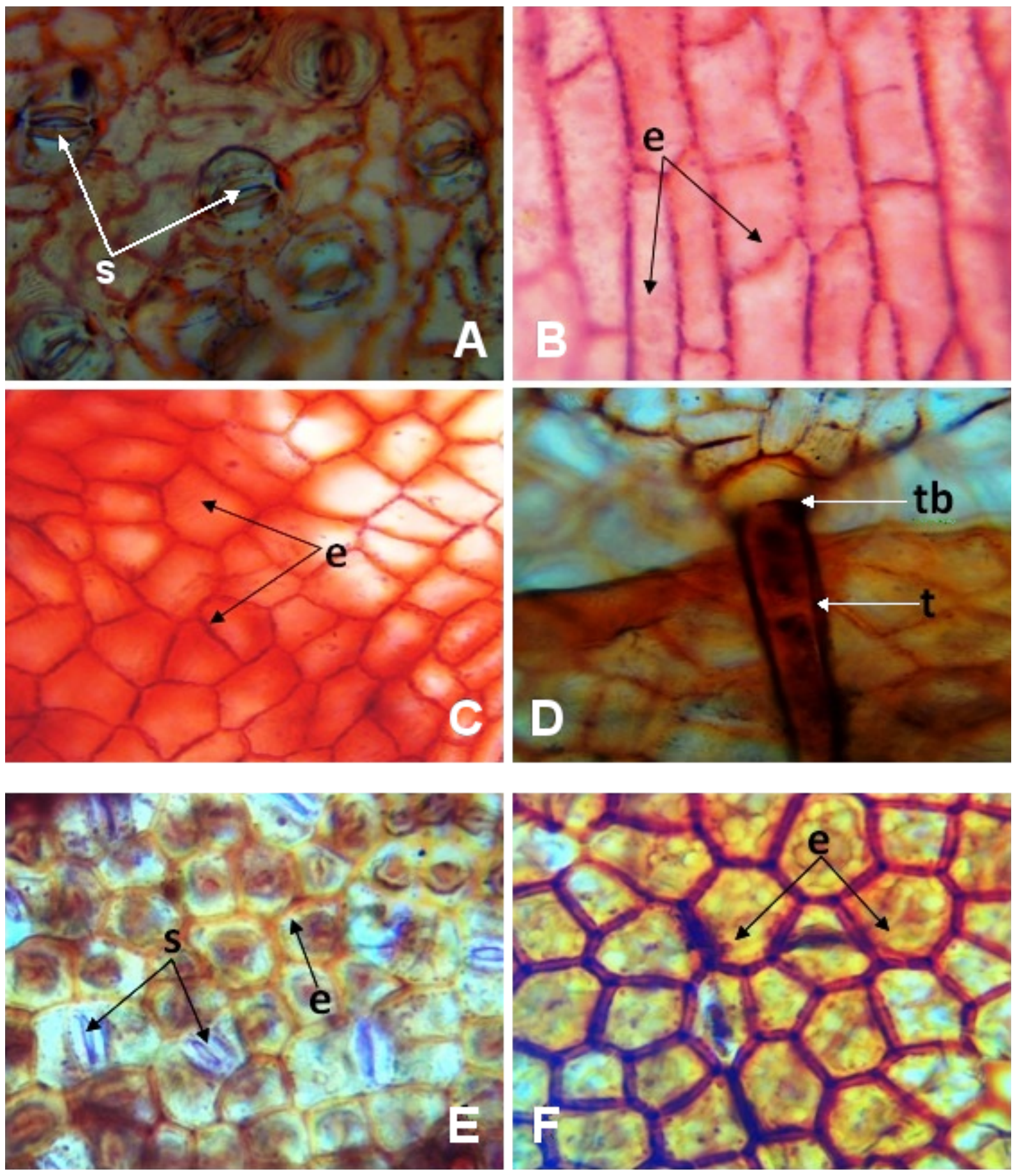

Figura 2. Fotografía de las superficies epidémicas x400. A, B: J. integerrima, superficie abaxial; C, D: J. integerrima, superficie adaxial; E: J. podagrica, superficie abaxial; F: J. podagrica, superficie adaxial. e: célula epidérmica; s: estoma; t: tricoma; tb: base del tricoma.

Figure 2. Photomicrographs of epidermal surfaces $\mathrm{x} 400$. A, B: J. integerrima, abaxial surface; C, D: J. integerrima, adaxial surface. E: $J$. podagrica, abaxial surface; F: J. podagrica, adaxial surface. e: epidermal cell; s: stomata; t: trichome; tb: trichome base. 


\begin{tabular}{|c|c|c|}
\hline Phytocompounds & $\begin{array}{c}\text { Jatropha } \\
\text { integerrima }\end{array}$ & $\begin{array}{c}\text { Jatropha } \\
\text { podagrica }\end{array}$ \\
\hline Alkaloids & $1.21 \pm 0.07^{\mathrm{b}}$ & $0.98 \pm 0.04^{\mathrm{b}}$ \\
\hline Cardiac glycosides & $2.35 \pm 0.12^{\mathrm{c}}$ & $1.27 \pm 0.05 \mathrm{~b}$ \\
\hline Flavonoids & $11.61 \pm 0.55^{\mathrm{e}}$ & $6.29 \pm 0.23^{\mathrm{d}}$ \\
\hline Phenols & $14.90 \pm 0.84^{\mathrm{f}}$ & $7.93 \pm 0.55^{\mathrm{e}}$ \\
\hline Phytosteroids & $0.42 \pm 0.01^{\mathrm{a}}$ & $0.42 \pm 0.01^{\mathrm{a}}$ \\
\hline Saponins & $0.81 \pm 0.35^{\mathrm{a}}$ & $0.49 \pm 0.02^{\mathrm{a}}$ \\
\hline Tannins & $8.13 \pm 0.60^{\mathrm{d}}$ & $4.43 \pm 0.05^{\mathrm{c}}$ \\
\hline
\end{tabular}

All measurements are in $\mathrm{mg} / \mathrm{g}$ and expressed as mean \pm standard error. Values with the same letters are not significantly different at $\mathrm{P}<0.05$

Tabla 2. Contenido cuantitativo fitoquímico de las hojas de las especies estudiadas de Jatropha.

Table 2. Quantitative phytochemical content of the leaves of Jatropha species studied.

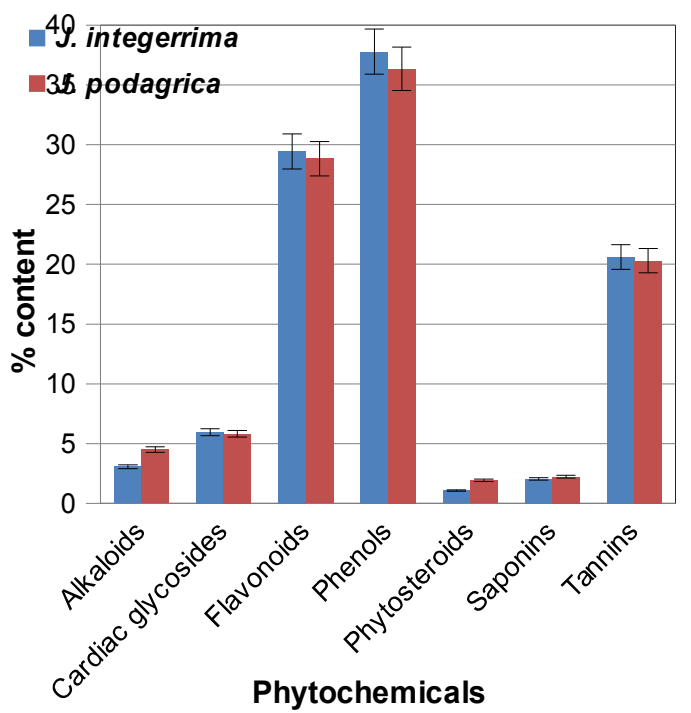

Figura 3. Porcentaje de contenido e fitocompuestos en las hojas de las especies estudiadas de Jatropha.

Figure 3. Percentage content of phytocompounds in the leaves of Jatropha species studied.

(1927) stressed that the number of stomata is higher, when the size of epidermal cells is low and the number of stomata is lower, when the size of the cells is large. This fact was also observed in this work. However, the taxonomic use of leaf epidermal characters had earlier been reviewed by some workers (Wilkinson 1979, Stace 1989), while the advantages and disadvantages of using such characters as taxonomic indicators have also been earlier conversed by others (Van Staveren \& Bass 1973, Soladoye, 1982).

Further findings from the phytochemical screening showed that the phenolic and flavonoid contents in both species where higher that other phytocompounds (Table 2). This was closely followed by tannin with $8.13 \pm 0.60 \mathrm{mg} / \mathrm{g}$ in $J$. integerrima and $4.43 \pm 0.05 \mathrm{mg} / \mathrm{g}$ in J. podagrica respectively. The large amounts of flavonoids $(11.61 \pm 0.55 \mathrm{mg} / \mathrm{g}$ in $J$. integerrima and 6.29 $\pm 0.23 \mathrm{mg} / \mathrm{g}$ in $J$. podagrica) could lead to the assumption that the examined species may have potent anti-oxidant properties. The tannin content as observed is an indication that the species are important in antibacterial, antiviral and antiparasitic drugs production (Akiyama et al. 2001, Kolodziej \& Kiderlen 2005, Soladoye \& Chukwuma 2012). Interestingly, the contents of phytosteroids is the same in both species. Although the presence of this compound as well as saponins in the examined plant species was not very significant, it also suggests their usefulness in drug industry, especially phytosteroids due to its relationship with sex hormones as noted by Okwu (2001). Asl \& Hossein (2008) also noted that there is evidence of saponins in traditional medicine preparations, where oral administration might be expected to lead to hydrolysis of glycoside from terpenoids.

As generally observed the epidermal cell sizes, cell wall thickness and the stomata size were variable and overlapping between the two Jatropha species, and as such, they may not be useful in the characterization of these two species even though they have added to existing taxonomic information regarding them. Also, the phytochemical content in the examined species can be summarised thus: phenols $>$ flavonoids $>$ tannins $>$ cardiac glycosides $>$ alkaloids $>$ saponins $>$ phytosteroids, as illustrated in figure 3 .

As observed in this work, it is noteworthy that the non-availability of species is a great hindrance to taxonomic studies. It is therefore imperative to encourage the sustainable collection and use of medicinally important species, not only of the Nigerian flora but of the world at large. By so doing, species extinction can be mitigated.

\section{Conclusión}

This study has further revealed that members of the genus Jatropha could be relied upon for several medicinal properties. The two species examined in this work ( $J$. integerrima and $J$. podagrica) both possess a number of useful phytocompounds in appreciable amount, thus suggesting that they could serve as potential sources of useful drugs in the near future if they are further screened for pharmacognostic properties. Nonetheless, the foliar epidermal studies also conduc- 
ted showed that they share similar anatomical features, yet some of these characters can be useful in delimiting the studied taxa. Such include the presence of trichome only on the adaxial surface of $J$. integerrima and totally absent on its abaxial surface as well as both surfaces of J. podagrica Although this study has added to the existing information about the two species, it however recommends that practical conservation strategies be adopted for the protection of important plant species such as those examined in this work.

\section{References}

Abdulrahaman AA, Kolawole OS, Mustapha OT \& Oladele FA. 2014. Palynological and Carpological Features of Four Jatropha species (Euphorbiaceae) as Taxonomic Characters. NISEB Journal 14(1): 3842

AbdulRahaman AA \& Oladele FA. 2010. Stomatal complex types, stomatal density and stomatal index in some Jatrophaspecies L. (Euphorbiaceae). Nigeria Journal of Pure \& Applied Sciences 23:2160-2163.

Adedeji O. 2004. Leaf epidermal studies of Emilia Cass. (Senecioneae, Asteraceae) in Nigeria. Botanica Lithuania, 10(2): 12-133.

Aiyegoro OA \& Okoh Al. 2010. Preliminary phytochemical screening and in vitro antioxidant activities of aqueous extract of Helichrysum longifolium DC. BMC Complimentary and Alternative Medicine 10: 21.

Aiyelaagbe OO, Adesogan EK, Ekundayo O \& Adeniyi BA. 2000. The antimicrobial activity of roots of Jatropha podagrica (Hook). Phytotherapy Research, $14,60-62$

Aiyelaagbe OO, Adesogan EK, Ekundayo O \& Hassanali A. 1998. Antifeedant activity of Jatropha podagrica roots. Fitoterapia 69: 175-176.

Aiyelaagbe OO \& Gloer JB. 2008. Japodic acid, a novel aliphatic acid from Jatropha podagrica Hook. Records of Natural Products 2(4), 100-106.

Akiyama H, Fujii K, Yamasaki O, Oono T \& Iwatsuki K. 2001. Antibacterial astion of several tannins agains Staphylococcus aureus. Journal of Antimicrobial Chemotherapy 48(4): 487-491.

AsI MN \& Hossein H. 2008. Review of pharmacological effects of Glycyrrhiza sp. and its bioactive compounds.-Phytotherapy Research 22(6): 709-724.

Berg AJV et al. 1996. Podacycline A and B, two cyclic peptides in the latex of Jatropha podagrica. Phytochemistry 42(1), 129-133.

Bhaskarwar B, Itankar P \& Fulke A. 2008. Evaluation of antimicrobial activity of medicinal plant Jatropha podagrica (Hook). Romanian Biotechnological Letters 13(5): 3873-3877.

Brunner JH. 1984. Direct spectrophotometric determination of saponin. Analytical Chemistry, 34: 1314-1326.

Chukwuma EC, Soladoye MO \& Abdus Salaam KRP. 2014. Taxonomic value of the leaf micro-morphology and quantitative phytochemistry of Clitoria ternatea and Centrosema pubescens (Papilionoideae, Fabaceae). Phytologia Balcanica 20 (1): 3-8.

Edeoga HO, Okwu DE \& Mbaebie BO. 2005. Phytochemical constituent of some Nigerian medicinal plants. African Journal of Biotechnology, 4: 685-688.

Ee GCL, Lim CK, Taufiq-Yap YH \& Go R. 200). Ferulic acid ester from Jatropha podagrica (Euphorbiaceae). Malaysian Journal of Chemistry, 7(1): 45-48.

El-Olemy MM, Al-Muhtadi FJ \& Afifi AFA. 1994. Experimental phytochemistry: A laboratory manual. Saudi Arabia: King Saud University Press,.

Harborne JB. 1973. Phytochemical methods, London. Chapman and Hall, Ltd. 278 pp.

Holmgren PK, Keuken W \& Schofield EK. 1990. Index Herbariorum Part I: The Herbaria of the World. 8th Ed. New York: International Association for Plant Taxonomy and New York Botanical Garden,.

Irvine FR. 1961. Woody plants of Ghana, 2nd ed. London: Oxford University Press.

Khatijah HN \& Zaharina MS. 1998. Comparative leaf anatomical studies of some Sterculia L. species (Sterculiaceae). Botanical Journal of the Linnean Society 127: 159-174.

Kolawole O S, AbduIRahaman AA \& Oladele FA. 2014. A Numerical Approach to the Taxonomy of the Genus Jatropha Linn. using Quantitative Phytochemical Constitutents. European Journal of Experimental Biology 4(6):71-76.

Kolawole O S, Abdul Rahaman AA, Jimoh MA \& Oladele FA. 2016. Morphometric study of the Genus Jatropha Linn. (Euphorbiaceae) in Nigeria. Notulae Scientia Biologicae 8(2): 211-215.

Kolawole OS, Omokanye BS, Ayesa SA \& Adewumi GA. 2014. Quantitative Phytochemical Screening of three Medicinal species of the genus Jatropha in Nigeria. Jewel Journal of Scientific Research 2(1\&2): 28-34.

Kolodziej H \& Kiderlen AF. 2005. Antileishmanial activity and immune modulatory effects of tannins and related compounds on Leishmania parasitised RAW 264.7 cells. Phytochemistry 66(17): 2056-2071.

Kupchan SM, Sigel CW, Matz MJ, Saenz Renauld JA, Haltiwangar RC \& Brayn RF. 1970. Journal of the American Chemical Society 92, 4476-4477.

Obadoni BO \& Ochuko PO. 2001. Phytochemical studies and comparative efficacy of the crude extracts of some homostatic plants in Edo and Delta States of Nigeria. Global Journal of Pure and Applied Sciences 8(2): 203-208.

Odebiyi OO. 1985. Steroids and flavonoids from Jatropha podagrica stem bark. Fitoterapia 56: 302303.

Okwu DE. 2001. Evaluation of the chemical composition of indigenous spices and flavouring agents. Global Journal of Pure and Applied Sciences 7(3): 455-459.

Oladipo OT \& IIloh HC. 2012a. Comparative wood anatomy of some members of the genus Jatropha (Euphorbiaceae) found in Nigeria. Phytologia Balcanica 18 (2): 141-147.

Oladipo OT \& Illoh HC. 2012b. Leaf Protein Electrophoresis and Taxonomy of Species of Jatropha L. (Euphorbiaceae). Notulae Scientia Biologicae 4(3): 92-96.

Oladipo OT, Illoh HC \& Odekanyin OO. 2008. Crude 
protein electrophoresis of seeds of four Nigerian species of Jatropha Linn. (Euphorbiaceae). Ife Journal of Science 10(2): 263-267.

Salisbury EJ. 1927. On the causes of and ecological significance of stomatal frequency, with special reference to the woodland flora. Philosophical Transactions of the Royal Society B 216: 1-65.

Sanni SB, Behm H, Beurskens PT, Adesogan EK \& Durodola JI. 1988. The crystal and molecular structure of $1 R, 3 S, 5 S, 10 R,-3,6,6,10,14$,-pentamethyltricyclo [10.3.0.0] pentadeca-11,14-diene1,10-dihydroxy-2,13-dione (Japodagrol). Journal of Crystallographic and Spectroscopic Research 18: 575-582.

Soladoye MO. 1982. Leaf epidermal studies in the African Baphia Lodd. and related genera (Papilionoideae-Sophoreae). Bulletin du Jardin Botanique National de Belgique 52: 415-437.

Soladoye MO \& Chukwuma EC. 2012. Phytochemical analysis of the stem and root of Cissus populnea (Vitaceae)-an important medicinal plant in Central
Nigeria.-Phytologia Balcanica, 18(2): 149-153.

Soladoye MO, Ariwaodo JO, Ugbogu OA. \& Chukwuma EC. 2011. A Morphometric study of species of the Genera Sterculia Linn. and Eribroma Pierre (Sterculiaceae) in Nigeria. Nigerian Journal of Botany 24 (2): 192-210.

Stace CA. 1989. Plant Taxonomy and Biosystematics, London: Edward Arnold Publishers, 264pp.

Trease GE \& Evans MC. 2005. Pharmacognosy.

New Delhi: Elsevier.

Van Staveren MGC \& Bass P. 1973. Epidermal leaf characters of the Melesian Icacinaceae. Acta Botanica Neerlandica 22: 329-359.

Van-Burden TP \& Robinson WC. 1981. Formation of complexes between protein and tannin acid. Journal of Agricultural and Food Chemistry 1: 77.

Wilkinson HP. 1979. The plant surface (mainly leaf). In Metcalfe CR \& Chalk L. (eds.) Anatomy of the dicotyledons, pp. 97-165. Oxford: Clarendon Press. 